\title{
THE ROLE OF SHARING CREATIVE IDEAS: PROFESSIONAL DESIGNERS ABOUT THEIR WORK
}

\author{
Paulina ROJEK-ADAMEK \\ Institute of Philosophy and Sociology, Faculty of Social Sciences, Pedagogical University of Cracow, \\ Ul. Podchorążych 2, 30-084 Kraków, Poland
}

Received 7 April 2021; accepted 10 June 2021

\begin{abstract}
A characteristic feature of the transition from industrial to post-industrial society is basing a significant part of production on the "intangible" value (software production, audiovisual production, advertising, design, cultural activities, etc.). The individual is perceived as the main actor in management processes where professional success depends on readiness for dialogue and exchange of owned capital (not only economically). It means a different definition of work, perceiving it as an element of shaping - understood in many dimensions - social, economic and cultural relations. Dematerialization of work means therefore giving primacy to the handling of information. This phenomenon can also be seen as a manifestation of cognitive capitalism characterized as a different accumulation system which is based on knowledge and creativity, in other words, on forms of intangible investment. Therefore, it seems that it would be particularly valuable to examine the potential of groups that have this knowledge capital as the basis of their activity. The article will discuss the theoretical concept of the exchange and sharing of creative ideas in the design field. It also presents original research devoted to this issue, conducted in the environment of Polish designers.
\end{abstract}

Keywords: co-design, creativity, design, of-sharing, social exchange.

\section{Introduction}

In modern society, knowledge is one of the basics of the capital which effectively generates economic profits. As sociologists say - work ceases to be directly related to activities aimed at supporting human life, it is no longer associated with the natural life cycle subordinated to nature, it is "denatured" (Marody \& Giza-Poleszczuk, 2004, pp. 244-248). The distinctive new relationships in the transition period from industrial to post-industrial society, in fact, support a significant portion of the production of "intangible" values (production software, audiovisual production, advertising, design, cultural activities, etc.). Thus, in post-industrial society one of the most important forms of capital accumulation is services - especially professional and technical services. The sphere of work resembles a game between people

*Corresponding author. E-mail: paulina.rojek-adamek@up.krakow.pl

Copyright (c) 2021 The Author(s). Published by Vilnius Gediminas Technical University

This is an Open Access article distributed under the terms of the Creative Commons Attribution License (http://creativecommons. org/licenses/by/4.0/), which permits unrestricted use, distribution, and reproduction in any medium, provided the original author and source are credited. 
(Bell, 1998, p. 184). It is also worth noting that this is accompanied by major changes in management science with new forms of work organization that are based on an understanding of contemporary economic processes, the activities of institutions with transnational coverage, and the phenomenon of globalization. As Drucker said, in today's developed society, knowledge management is central:

"By the late sixties or early seventies it was becoming clear that the knowledge on which the management boom was founded no longer sufficed. Even in most of the foundation areas there emerged needs for new knowledge, particularly with respect to productivity, organization design and structure, and the management of people. Scientific management could no longer deliver increased productivity" (1973, p. 25).

In post-industrial society we observe a different perception of work - it is recognized by social, economic and cultural relationships. It produces relations of innovation, gives information and intellectual property as products, but all efforts, however, serve to create economic value (Lazzarato, 2021). Such dematerialization of work gives primacy to information exchange in the work process, focusing on the intangible aspects in the sphere of production and consumption of crossing borders and the role attributed to social networks (Castells, 2008; Moulier Boutang, 2011). This means that the modern market and the processes related to it, e.g. in the area of management and immaterial capital production, are quite willing to turn to areas that can express new aspirations. Design is undoubtedly such a field. Design even begins to be perceived as necessary, immanent in various manufacturing and service sectors; from everyday objects (clothes, shoes, cars) to designing services (e.g. related to hunger or travel) - the economy is saturated with design (intensive) (Lash \& Urry, 1994, p. 6; Scott, 1988, p. 175). Taking their place alongside other professionals providing similar values, designers are also part of the relational systems, which entails the need to develop new skills, including cooperation in the context of social networks. The purpose of the article is to show the role of communication and the exchange of creative ideas as part of co-creating solutions. Design practice, understood as a social process with economic consequences, is not possible without the willingness to act together and share knowledge and ideas, as in many other production areas within the creative sectors.

Many studies devoted to the problem of sharing knowledge and ideas in the sphere of work are focused around the question, how does this affect the management of the company and what are the benefits to a particular organization? In this case, we will not be interested in a collective entity (organization), but rather individual entities along with their perspective on the role of these processes. We will take this approach because - although the designer profession requires cooperation - practitioners often work as specialists who are independent of the organization. They are often entrepreneurs themselves, they are freelancers, not employed full-time by any one organization. Therefore, they frequently remain "outside" the organization with which they cooperate. For the management processes, it gives them a place outside the "system", away from the direct influence of the organizational culture of the institution (although often in close relation with it). Hence, the adopted perspective is very individual and goes beyond describing the ways of working that would be determined by primarily pursuing the objectives and values that are important to the organization. Therefore, the main goal of the article is to show how sharing of creative ideas (knowledge) with other 
professionals is understood and implemented in the practice of design. It seems particularly valuable to examine the potential of groups that have knowledge capital as their basis.

The questions that should be asked first of all in the analysis relate to how much these groups (their representatives) are ready to "give" their own ideas, their concepts for solving the problem, to others? What is their attitude toward interdisciplinary work, in which the final result of the work cannot be due to the merit of the individual, but rather a team ready for dialogue and exchange? And finally, are there any special features of the representatives of the creative class that affect their attitude to the issue of exchange understood in this way as a gift? To achieve this goal, nationwide empirical research was conducted in 2018/2019 among professional designers using the survey technique. The presented text will report selected conclusions that relate directly to the topic.

\section{Theoretical framework}

\subsection{Meaning of exchange in social sciences}

The issue of sharing or exchange, in terms of knowledge and its management problem, can be considered in different theoretical perspectives. It can be analyzed by taking into account the sphere of management (Drucker, 1994; Takeuchi \& Nonaka, 1986; Krogh et al., 2013) or as a work-related psychological processes of knowledge creation, analyzed as problem of developing innovative potential. New information is perceived as the result of explicit and tacit knowledge exchange during interactions between individuals, teams, organizations and the environment (Nonaka, 1994, 2007). The problem of exchange can also represent the view of social sciences such as anthropology or sociology, embedded in the paradigm of social exchange theory which assumes a fairly broad cognitive perspective concerning both the course of the exchange itself (dependence on the relationship, on the network of connections) and its result (capital accumulation, multiplication of resources, shared experience, etc.) which is singularly useful for this article. Fully discussing the basic assumptions of social exchange theory is impossible in a few paragraphs. The theory of exchange is quite complex and varied in its assumptions, derived not only from the work of sociologists, but also psychologists, economists and, perhaps above all, anthropologists. The latter, by examining kinship relationships and family ties, sought reasons for the establishment of order and bond in certain communities to ensure a secure relationship. Although their views were not uniform (from utilitarian views based on economic interests that underlie the creation and consolidation of cultural patterns (Frazer, 2015) to their rejection (Malinowski, 1986), bringing exchange to supra-individual dimensions (Mauss, 2007) and assigning the structural importance of the exchange are important for the integration of social structures (Levi-Strauss, 1992). For sociologists, especially those interested in the significance of the exchange of material, the position of the individual in economic systems or the value of money in exchange, the works of Marks (1951) and Simmel (1997). However, the perspective of social exchange is primarily associated with American researchers including Homans (1974), Blau (1987, 2017), Coleman (2009) and Emerson $(1962,1992)$, combining both the approach of economic utilitarianism and psychological behaviorism. Researchers not only understood the concept of exchange 
differently or used different inspirations, but also sought to apply it in various areas of analysis - from issues at the level of social microstructure to issues important for understanding the organization of macrostructures. Therefore, this concept was used to examine family relationships, social ties in primary groups, analyzing work environments, exercising privileges and power, and examining organization and inter-organizational relationships. It is worth noting that, in the case of research on relational systems, as it is in the context of this article's topic, researchers should not ignore the network theory of exchange (including Emerson), which, although it primarily refers to the world of economics, concerns the choices of the individual which are the most favorable for their position in a given environment (social network). As Drucker (1973) wrote, knowledge is key to post-modern society. However, knowledge and the related need to base management processes on it will not be productive until the employee finds out what they are, what kind of work is best suited to them, in what conditions, and what relationships work best.

In this particular case, i.e. the description of designers' work, sharing will be understood as the process of the exchange of creative ideas during the common work on the project. We assume that it primarily concerns the designers' environment and their knowledge capital, which has many common elements as a result of preparing for a professional role. Although, of course, there are internal variations - designers may differ in habitus within the field, some may have more capital than others; they may also have different types of resources - social, cultural; they may finally take different positions within the environment. Despite this, however, it is a relatively homogeneous environment. This means there are no actors without capital, but there are different strategies for accumulating it and creating networks that support its multiplication. The key difference, however, is the type of knowledge that designers use, depending on the specialty of the design area. Therefore, in this particular case, it is much easier to analyze the exchange of creative ideas than the exchange of specialist knowledge resources. The reason for researching the designers' environment is, inter alia, that it is often a profession that means "working on a project" with others. Each project involves different actors (sometimes also non-designers), different rules. Hence, it is difficult to predict which ones will prove effective for a given relational system. There is no doubt, however, that it is a profession that a priori assumes - especially nowadays - the need to share. Therefore, the article will present the attitude toward the phenomenon of sharing in an environment of people who practice profession based on creativity.

\subsection{Design and role of sharing in design process}

The contemporary work of designers, now more than ever in the past, is based on cooperation and necessary exchange (ideas, knowledge, information). This is not only due to the changing definition of the concept of design itself, but also the development of design methods that put humans at the heart of the design process - i.e. recipients (user centered design), other specialists, principals, local communities, etc. Co-design (participatory design) implies not only gathering knowledge about the needs of the user, but above all, the active participation of different stakeholders in the whole process. Treated as a method is used to integrate social areas with elements of culture. It serves not only to solve business problems, but also increasingly 
creating social innovation processes (Chamorro-Koc \& Caldwell, 2018). The process of designing products and services is interdisciplinary, based on interaction and exchange:

"Today it is not business as usual anymore. The rules have changed and continue to change. The new rules are the rules of networks, not hierarchies. People are cynical about the methods and goals of consumerism. The users of products, interfaces, systems, and spaces are realizing that through networking they have an enormous amount of collective influence" (Sanders, 2002, p. 2).

Defining design is not a simple task. First, the word design is both a noun and a verb. It is described as an activity - the design process - and at the same time design is also the result, the effect/work of the designer. Design is defined by various researchers with a different range of designations. Traditionally, design that dates back to the 19th century and the industrial revolution was mainly discussed in the context of product design and the use of the industrial technology of those times. However, since then, a lot has changed and design began to appear in very different contexts and areas of professional activity. Design has been redefined with subsequent additions generated by the need to expand the scope of its application (from products to services, strategy and organization management), and to include more and more new actors in the field of design (from experts from various disciplines to end users) (Manzini, 2015, p. 53). Some theorists even accept that design means almost everything we do, and therefore a lot of activities in various professions can be treated as a specific type of design. Such ways of understanding the term can certainly include descriptions of two significant researchers in the field of science and design - Papanek and Simon (Papanek, 2005; Simon, 1996). The first of these authors wrote in a very influential publication Design for the Real World: Human Ecology and Social Change that all men are designers and design (as a process) is a basic to all human activity (Papanek, 2005). The other, apart from the fact that he understood design primarily as a way of solving problems, also wrote about calling designers representatives of very diverse professions (Simon, 1996). According to his view, design concerns anyone who invents directions for action to change an existing situation into a preferred one (Simon, 1996). From this perspective, design is, firstly, a way of using knowledge to achieve a goal and this knowledge can be varied - from engineering, through medical, technical, and ergonomics to knowledge of aesthetics or social sciences and humanities.

Traditionally, design refers to objects - what they are, how they work or meet our needs, etc. Nowadays, the designers' scope of interest is also conscious of building relationships and formulating specific modes of action, which currently places design outside the material object, in the area that we call service design. As Manzini (2015) wrote, the right to use the double meaning of design (beyond the purely material creation) is the fact that many other products of human activity are embedded in two worlds: the physical/biological (where people live and where things work) and the social (where human beings talk and things get meaning). Therefore, it is difficult to restrict the definition of design to only designing physical elements. There is no doubt that the traditional, narrow definition of design, as an artistic creation of luxury, stylish goods reserved for elite customers, gives way to the scientific literature and managerial definition, which perceives design as a process leading to innovative solutions in the fields of products, services or communication with the accompanying aesthetic value of the proposals 
offered. In this perspective, design becomes an area of a wide range of activities. Although it is impossible to have one comprehensive definition of design, which is also a consequence of the large diverse area of design specialties, it can be assumed that the general definition proposed by the World Design Organization (WDO) (2021) meets our expectations. According to WDO, design - even that which is concerned with industrial design problems -

\begin{abstract}
"[...] is a strategic problem-solving process that drives innovation, builds business success, and leads to a better quality of life through innovative products, systems, services, and experiences. [...] bridges the gap between what is and what's possible. It is a trans-disciplinary profession that harnesses creativity to resolve problems and co-create solutions with the intent of making a product, system, service, experience or a business, better. [...] It links innovation, technology, research, business, and customers to provide new value and competitive advantage across economic, social, and environmental spheres" (2021).
\end{abstract}

Design treated as a "problem solving" tool and as a way of approach (methodology) with a wide range of possibilities of use, also outside the material categories, more often becomes the strategic core of public and corporate policy. Therefore, the use of design is consequently also associated with a change in perception of the role of the designer. Many researchers are currently observing that there are "new types" of designers who are willing to take on the role of an expert in creating places for local communities; such as a designer-activist working to change cultural attitudes and behavior or for a design and production micro enterprise operating within networks. The common denominator is that all are gradually shifting from dealing with traditional products and artifacts communication to design processes, which must be designed as hybrid dynamic artifacts, in which products, services and communication are systematized and presented as a whole (Manzini, 2015, p. 43). This is why design is perceived as a form of communication, in which the methodological way to approach the design process is described as a design thinking approach. This perspective assumes (regardless of whether the design involves a product or services) sharing knowledge and exchanging creative ideas, using cognitive tools from disciplines such as anthropology, ethnography or sociology. In addition, it assumes team and interdisciplinary work.

The designer and theoretician of design, Shaughnessy said that, apart from talent and abilities, the most important features of a designer can be reduced to three things: cultural awareness, honesty and communication skills, thanks to which the process of sharing knowledge has a chance to exist not only as a need, but is also implemented in everyday practice (2012, p. 33). Designers are no longer just experts in giving form, but often become links between parties of different interests. Therefore, developing the final solution with the help of traditional design tools is now only part of their work and expected commitment. Nowadays, this profession is based not only on a set of specific skills or a creative vision of creating something unique (works in artistic categories), but has become a profession combining those skills with knowledge management to serve - as designers say - as a way of "solving problems" or "building relationships". By adopting such a work methodology, it is impossible to effectively implement a design process without openness and willingness to exchange intangible assets. Although this seems obvious, in practice it can be a difficult task. In this case, we are dealing with a very specific work environment - a talented, creative environment. In addition to this uniqueness, it also has - treated as a field as described by Bourdieu (1996) 
for the role of artist, scientist - specific rules of the game for which the basic capital of the participants is their cultural and social capital. Their capital determines success in the field of immaterial labor, which may exacerbate the phenomenon of resistance to genuine sharing.

The exchange of ideas can be treated as a stake in the game for the position of an actor. Therefore, it seems interesting to examine attitudes and readiness to exchange in such a unique environment as that of the designer. It should be noted, however, that the purpose of interviews with designers was not a detailed analysis of the knowledge exchange process with all its conditions. Rather, it was a look at the importance of the problem of sharing, which - as was shown - in this specific environment ceases to be a choice, and becomes an immanent part of the designer profession.

\section{Research methodology and sample characteristics}

\subsection{Research gaps and questions}

The presented results are unpublished part of a larger research project implemented in 2018/2019 among Polish designers. The main research question in this part of the research focused on the description of the professional role of the designer and the field of design along with an analysis of the readiness of designers to cooperate and share knowledge and creative ideas.

\subsection{Methods and sample population}

The research was carried out using the qualitative and quantitative research method. This text will present the results of a survey conducted using a survey technique, which, in the context of the problem, was supposed to provide the most honest answers possible, not disturbed by the presence of the researcher, which can happen during in-depth interviews.

The group of designers was selected using criteria concerning education and experience in the profession. The method of reaching designers was two-stage and involved: in the first stage - establishing contact with designers from databases available on websites devoted to design (see Wzornictwo Biznes Zysk, 2021), associated in the Association of Industrial Designers (AID) and the Association of Graphic Designers, and with designers who are known to the researcher because of his professional relationships (knowledge of the environment and institutions bringing together designers); in the second stage - selection of the sample using the snowball method.

\subsection{Data collection and analysis}

The sample of $\mathrm{N}=102^{1}$ professional designers (52\% women and $48 \%$ men) was limited to graphic and industrial design specialists. The most of the group were relatively young designers,

\footnotetext{
1 The sample size is considered relatively large as for Polish conditions. It is similar or even higher than in other national studies concerning this sector (e.g. the special report (Palczewska et al., 2017), $\mathrm{N}=30$ ). The reasons for the low market activity of design's graduates may be the result of, inter alia, a situation in which about $90 \%$ of graduates do not work (according to the AID) and a relatively low Global Creativity Index for Poland (in 2015, out of 139 countries, Poland was ranked 46th, with an index of 0.516 (Florida et al., 2015)).
} 
i.e. up to 39 years of age ( $75.5 \%$ ), the age of $40-55$ declared $21.6 \%$, and above 56 years $-2.9 \%$. The study had national character. Participated designers are most often employed full-time (47.1\%) or run their own business $(42.2 \%)$. Only about $5 \%$ chose the answer indicating the combination of these two forms or the lack of permanent employment (being a freelancer). Every fourth respondent of the designer described work primarily as individual work. This group is dominated by women and non-members in any organization that brings together projects. Teamwork was more often indicated by men and members of the associations (twice as many men as women and twice as many association members as non-members).

\section{Results and discussion}

The work of designers is based on cooperation. Nearly $3 / 4$ of the respondents considered teamwork as a dominant, although only $23 \%$ of this group stated - definitely yes. The form of employment of the respondent does not have much influence on the answers. In each of the forms, the need to combine individual work with team work was definitely the most frequent. Designers who are running only their own business slightly more often indicated individual work as preferred (Figure 1).

For the topic of the article, this is a key result confirming the legitimacy of discussing such a topic. When working in a team, especially in a project team, it is difficult to avoid the need to exchange intangible goods, although it is not always accompanied by sincere readiness and openness. Therefore, the goal was to assess precisely the extent to which sharing ideas is important, necessary and internalized as a personal attitude. In each of the questions, an identical scale was used to assess the issues examined, i.e., from 1 to 5, with 1 indicating the category chosen as the least important, and 5 the most important. All results will be presented as percentages and the average ratings calculated for each question.

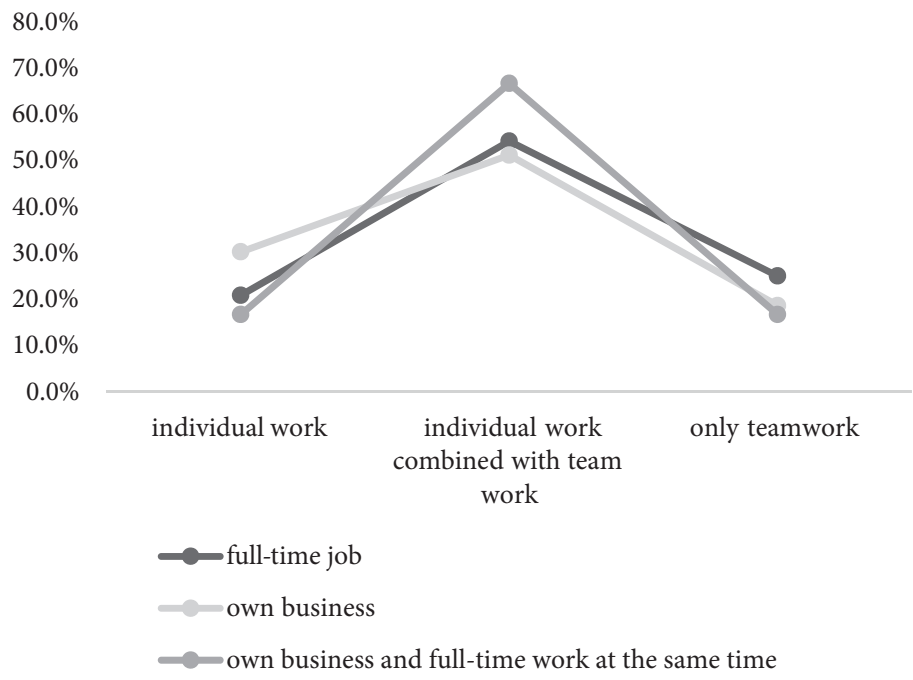

Figure 1. The form of employment and the work model $(\mathrm{N}=102)$ (source: created by author) 
The first of the issues referred to the perception of the phenomenon of sharing creative ideas in the design profession by responding to previously formulated possible arguments for undertaking such actions. According to the answers, it is, above all, an opportunity for respondents to broaden their knowledge and to exchange constructively critical remarks. In the analysis of means, these two categories obtained the highest values (Table 1).

Most often, sharing ideas as a form of expanding knowledge was indicated (the sum of answers "important" and "very important") by people running their own business (81\%) and combining full-time work with their own business (83\%). It should be noted, however, that not all proposals were at least rated at good level. Most categories received an average rating below 4.0. "Necessity" was as the least indicated category. This may suggest that if such a process takes place, it is most often seen as an arbitrary decision by the designer, not dictated by any external expectations of the group or team. It is worth noting, however, when looking at detailed percentage data, a lot of very positive indications have got the answer that sharing knowledge is part of creating a personal image. On the one hand, this is pretty obvious result, but on the other - if we assume that the design process implies the need to share - it can be considered as a manifestation of defending proprietary ideas, even when it might be conducive to working out by a group of the best solution.

The willingness to share creative ideas within the environment (in direct relations with other designers) was assessed at a moderate level. The results showed that none of the positions evaluated did not obtain maximum results (scale of 1 to 5 ), and the lowest rated category received only an average assessment of 2.7. The highest classification (3.5) was for the willingness to cooperate with others. This shows that, despite the declared importance of exchanging and sharing, the practice of daily relationships does not give a sense there is full reciprocity of such attitudes or readiness. Those who are perceived as willing toward such behavior, are not extremely common in the environment of designers. The least frequently indicated were those people who were ready to accept critical remarks. However, this is a conclusion that naturally correlates with the specificity of creative environments in a broader sense (Table 2).

However, it is essential to analyze in detail the reasons for attitudes toward the problem of sharing and exchanging knowledge. Although the answers are only declarations of the respondents (we have not tested in practice how the exchange works), they can be considered

Table 1 . Sharing in my work means (average rate, $\mathrm{N}=102 ; 1$ - very rare, 5 - very often) (source: created by author)

\begin{tabular}{|l|c|}
\hline \multicolumn{1}{|c|}{ DESIGNERS' ATTITUDE TO SHARING IDEAS } & AVERAGE \\
\hline An opportunity to broaden knowledge & 4.1 \\
\hline An opportunity to exchange constructively critical remarks & 4.1 \\
\hline Element of image creation & 3.9 \\
\hline Personal pleasure & 3.8 \\
\hline Way of building a professional position & 3.5 \\
\hline Ideas in my work serve the general good and it is a moral duty & 3.5 \\
\hline A necessity & 3.2 \\
\hline
\end{tabular}


Table 2. Do you often meet people in your professional environment who...? (average rate for the scale from 1 to $5, \mathrm{~N}=102$ ) (source: created by author)

\begin{tabular}{|l|c|}
\hline \multicolumn{1}{|c|}{ OTHER DESIGNERS ARE... } & AVERAGE \\
\hline ...focused on cooperation & 3.5 \\
\hline ...ready for an open exchange of thoughts & 3.3 \\
\hline ...brave in pushing controversial ideas, even when the client has a different position & 3.2 \\
\hline Encourage others to exchange thoughts and ideas & 3.1 \\
\hline Have no fear that someone will use their idea & 3.1 \\
\hline ...ready to accept critical remarks & 2.8 \\
\hline
\end{tabular}

as an important premise in searching for sources of possible conflicts during the work of project teams.

The most important issue is the designers' fear that someone may steal an idea. In this environment, as in many other creative environments where knowledge capital is not only an important tool to solve current professional problems, but above all, serves to generate unique and innovative solutions, protecting intellectual property is a special task. Although Polish law regulates selected issues in this area, many fields remain outside its provisions (e.g. inspiration from someone else's idea). It is not surprising that this category turned out to be crucial. Fear of criticism turned out to be the least important barrier, which is quite amazing in the light of previous answers. The lack of readiness to accept critical comments by other projects (the sum of answers "rarely" and "very rarely") was most often indicated by people running their own business (44\%). Among designers working full-time, $25 \%$, and among people combining both forms, only $16 \%$. The obvious conclusion leads to the statement that when talking about other designers, the respondents perceive them as poorly prepared for criticism, but when they think about themselves, the position is different. It is worth noting that, as in the previous questions, the values (average) for all categories were generally quite low (Table 3 ).

What motivates designers to share ideas and become more open without fear? In the case of this question, all the proposed conditions were rated quite high but the main motivation was the argument that it is the best way to find inspiration. The aspect of conversation and communication with others was also emphasized in the second condition, and expressed by the statement that motivation can be incentives from other team members. The lowest rated argument is that sharing ideas is a chance to convince others of your idea. It can be assumed that designers are looking for benefits for their own development through exchange, but they are quite skeptical when it comes to the possibility of influencing the opinions (beliefs) of others in this way (Table 4).

Looking at the detailed data, it can be seen that only one of the categories, i.e. "Shortening the time for the project work process", has not been rated by anyone as a very important motivation factor. This means that there are many reasons to share ideas, but this does not translate into increasing the speed of performing tasks. Interestingly, this answer diversified the most designers in terms of forms of employment. As a very important factor (the sum of 
Table 3. How would you rate the significance of the restrictions that can affect your willingness to share ideas? (average rate for the scale from 1 to $5, \mathrm{~N}=102$ ) (source: created by author)

\begin{tabular}{|l|c|}
\hline \multicolumn{1}{|c|}{$\begin{array}{l}\text { RESTRICTIONS THAT CAN AFFECT DESIGNERS } \\
\text { WILLINGNESS TO SHARE }\end{array}$} & AVERAGE \\
\hline Fear that someone might steal your idea & 3.8 \\
\hline Pressure and lack of time & 3.7 \\
\hline $\begin{array}{l}\text { Difficulties in understanding each other because of differences that are not always } \\
\text { stated explicitly (e.g. difference of interest) }\end{array}$ & 3.6 \\
\hline Insufficient contact (communication) with others & 3.6 \\
\hline $\begin{array}{l}\text { Uncertainty about the value of knowledge, idea (no certainty that it is relevant to } \\
\text { the discussion) }\end{array}$ & 3.5 \\
\hline Fear of ridicule & 3.1 \\
\hline Fear of criticism & 3.1 \\
\hline
\end{tabular}

Table 4. How would you rate the impact of various factors on the motivation to share ideas? (average rate for the scale from 1 to $5, \mathrm{~N}=102$ ) (source: created by author)

\begin{tabular}{|l|c|}
\hline \multicolumn{1}{|c|}{ DESIGNERS' MOTIVATION TO SHARE IDEAS } & AVERAGE \\
\hline Seeking inspiration by encouraging others to talk & 4.0 \\
\hline Encouragement from other team members & 3.9 \\
\hline Reciprocity, i.e. receiving important information in return & 3.9 \\
\hline Shortening the time of the project work process & 3.8 \\
\hline A chance to convince others of your idea & 3.8 \\
\hline
\end{tabular}

Table 5. How would you rate the following benefits from sharing ideas? (average rate for the scale from 1 to $5, \mathrm{~N}=102$ ) (source: created by author)

\begin{tabular}{|l|c|}
\hline \multicolumn{1}{|c|}{$\begin{array}{c}\text { BENEFITS THAT AFFECT THE DESIGNERS' WILLINGNESS TO SHARE } \\
\text { IDEAS WITH OTHERS }\end{array}$} & AVERAGE \\
\hline Building understanding and a good atmosphere at work & 4.3 \\
\hline A sense of contentment and satisfaction when others listen to me & 4.0 \\
\hline A sense of personal development & 4.0 \\
\hline Increased trust from other team members & 3.7 \\
\hline Increase of expert position in the eyes of others & 3.5 \\
\hline
\end{tabular}

answers "important" and "very important"), it was indicated by $83 \%$ of those working only full-time, compared to $65 \%$ running their own business and $67 \%$ combining both forms.

The last question directly concerns the assessing of benefits that can be a factor encouraging designers to share ideas. The most important reasons included, first of all, factors binding the group and a sense of internal satisfaction. Building agreement and a good atmosphere at work is the category that was considered the most important (average 4.3). Next, however, is the trait related to the role and position that the respondent sees for themself in the group - 
a sense of contentment and satisfaction when others are listening to me (4.0) - which may suggest the need to be perceived as an expert and appreciated by the other members of the team. Paradoxically, however, when we asked directly about this reason - the increase in expert position in the eyes of others - respondents placed it lowest in this ranking (3.5). The argument that sharing ideas can contribute to increasing trust on the part of other team members is not very significant (3.7). It is quite a surprising result in the light of the commonly accepted methodology of work as part of the design process (Table 5).

In this question, detailed data confirmed that the category "Building understanding and a good atmosphere at work" was definitely considered as the most important, i.e., it received the highest number of very high marks. In-depth percentage analysis, which included respondent variables such as gender, age and seniority, did not show significant differences in most of the answers, so were not detailed in the presented fragment of the research report.

\section{Conclusions}

It seems that most designers are relatively positive about various forms of behavior that allow the sharing of knowledge or ideas. Sharing means deepening knowledge, paying attention to important, and perhaps unnoticed, aspects of design problems. This may suggest that the exchange potential in this environment is very high. This does not mean, however, that despite those supporting the statement about the idea of sharing, designers are, in practice, very willing to such an exchange. Although they declare that sharing is important, most of them strive to maintain some degree of autonomy and their decision-making voice ("The feeling that others are listening to me"). Most designers adhere to the attitude of openness - but openness conditioned by the right to protect copyright solutions. Although the contemporary education of designers clearly separates their profession from education in the field of artistic professions, they will always have a common feeling of being a creator. The designer, however, is a bit of an artist who has original ideas and does not want, even in the name of group success, that others quickly adopt and recognize these as the team's property. Sharing is therefore important, but within the limits set by the designer and when it is actually an exchange, and thus a two-way process. Designers must share, because this is what design processes require, but they must also be able to set boundaries to prevent "black" co-design without a sense of fair exchange.

Based on a review of the literature and reported research, in summary we should emphasize the fact that the design process is a form of exchange. Observation of designers' ways of working shows that this - unlike purely artistic work - is not possible without sharing culture resources as knowledge, ideas without jointly formulated proposals for solutions and confronting them in the users' environment. This applies to both the creative stage and the verification of solution prototypes.

\section{Limitations and further research}

The reported research, as said at the beginning, was only for reference. It was a part of a project whose overarching goal was to describe the professional role of designers (exchange 
and sharing analysis was only one of the topics). Hence, one can get the impression of rather cursory and general statements. The author of the text, however, is fully aware of this, but the intention was primarily to draw attention to the fact that the chosen topic may be of interest and worth exploring. Consequently, one of the conclusions is that the analysis possibly needs to be deepened in a way that provides a more detailed map of the spread of the exchange relationship in the environment with all its conditions (with the example of a specific design process) and the opportunity to analyze the network of the designers' environment. So, it could be worth to develop the study with a more detailed understanding of cause-effect relationships e.g., in the scope of the preferred model of work and the form of employment of the designer was indicated. However, this requires a more detailed examination of the system of relations also with other groups of stakeholders. The world of designers is a field in which individual social objects are dependent, creating a fairly diverse and dynamic network structure. Therefore, it would be worthwhile to look how the flow of creative ideas and knowledge influence the dynamics of this network, number and frequency of ties.

\section{Acknowledgments}

This research received financial support as part of funds derived from the Pedagogical University of Cracow (PUC), Kraków, Poland statutory research. Project title Creative Class' Of Sharing: Tendency to Exchange and Knowledge Sharing among Representatives of Creative Sectors (National Education Commission (NEC), PUC, 2018/2019).

\section{Funding}

This work was supported by the PUC's statutory funds of NEC PUC.

\section{References}

Bell, D. (1998). Kulturowe sprzeczności kapitalizmu. Państwowe Wydawnictwo Naukowe.

Blau, P. M. (2017). Exchange and power in social life. Routledge. https://doi.org/10.4324/9780203792643

Blau, P. M. (1987). Microprocess and macrostructure. In K. S. Cook (Ed.), Social Exchange theory (pp. 83-100). SAGE Publications, Inc.

Bourdieu, P. (1996). Crossing aesthetics. The rules of art: Genesis and structure of the literary field. W. Hamacher \& D. E. Wellbery (Eds.). Stanford University Press.

Castells, E. (2008). Społeczeństwo sieci. Państwowe Wydawnictwo Naukowe.

Chamorro-Koc, M., \& Caldwell, G. (2018). Viable futures through design: Community engagement experiences in the creative industries. Creativity Studies, 11(1), 213-229. https://doi.org/10.3846/cs.2018.857

Coleman, J. S. (2009). Studies in rationality and social change. Individual interests and collective action: Selected essays. Cambridge University Press.

Drucker, P. F. (1973). Management: Tasks, responsibilities, practices. HarperCollins Publishers.

Drucker, P. F. (1994). Post-capitalist society. HarperCollins Publishers.

Emerson, R. M. (1962). Power-dependence relations. American Sociological Review, 27(1), 31-41. https://doi.org/10.2307/2089716 
Emerson, R. M. (1992). Stosunki wymiany i struktury sieci wymiany. In M. Kempny \& J. Szmatka (Red.), Współczesne teorie wymiany społecznej. Zbiór tekstów (pp. 396-438). Państwowe Wydawnictwo Naukowe.

Florida, R., Mellander, Ch., \& King, K. (2015). The global creativity index 2015. Martin Prosperity Institute.

Frazer, Sir J. G. (2015). Folk-Lore in the Old Testament. Vol. 2. Arkose Press.

Homans, G. C. (1974). Social behavior: Its elementary forms. Harcourt, Brace and World, Inc.

Krogh, von G., Takeuchi, H., Kase, K., \& González-Cantón, C. (Eds.). (2013). The Nonaka series on knowledge and innovation. Towards organizational knowledge: The pioneering work of Ikujiro Nonaka. St Martin's Press.

Lash, S., \& Urry, J. (1994). Economies of signs and space. SAGE Publications.

Lazzarato, M. (2021). Immaterial labor. Generation online. https://www.generation-online.org/c/fcimmateriallabour3.htm

Levi-Strauss, C. (1992). Zasada wzajemności. In M. Kempny \& J. Szmatka (Red.), Współczesne teorie wymiany społecznej. Zbiór tekstów (pp. 107-130). Państwowe Wydawnictwo Naukowe.

Malinowski, B. (1986). Argonauci zachodniego Pacyfiku. T. 3. Państwowe Wydawnictwo Naukowe.

Manzini, E. (2015). Design, when everybody designs: An introduction to design for social innovation. The MIT Press. https://doi.org/10.7551/mitpress/9873.001.0001

Marks, K. (1951). Kapitał. T. 1. Książka i Wiedza.

Marody, M., \& Giza-Poleszczuk, A. (2004). Przemiany więzi społecznych. Zarys teorii zmiany społecznej. Wydawnictwo Naukowe Scholar.

Mauss, M. (2007). Essai sur le don: Forme et raison de léchange dans les sociétés archaïques. Les Presses universitaires de France.

Moulier Boutang, Y. (2011). Cognitive Capitalism. Polity Press.

Nonaka, I. (1994). A dynamic theory of organizational knowledge creation. Organization Science, 5(1), 14-37. https://doi.org/10.1287/orsc.5.1.14

Nonaka, I. (2007). The knowledge-creating company. Harvard Business Review. https://hbr.org/2007/07/ the-knowledge-creating-company

Palczewska, I., Ginalski, J., Gwiazda, M., \& Kalka, J. (2017). Sukces w zawodzie projektanta wzornictwa przemysłowego: czynniki i mechanizmy wpływające na efektywna wspótpracę między projektantami $i$ przedsiębiorcami wdrażającymi nowe produkty na rynek oraz kształtujące rozwój kariery zawodowej projektanta. Raport z badań. Instytut Wzornictwa Przemysłowego.

Papanek, V. (2005). Design for the Real World: Human ecology and social change. Academy Chicago Publishers.

Sanders, E. B.-N. (2002). From user-centered to participatory design approaches. In J. Frascara (Ed.), Design and the social sciences: Making connections (pp. 1-8). Taylor \& Francis/Contemporary Trends Institute. https://doi.org/10.1201/9780203301302.ch1

Scott, A. J. (1988). Flexible production systems in regional development: The rise of new industrial spaces in North America and Western Europe. International Journal of Urban and Regional Research, 12(2), 171-186. https://doi.org/10.1111/j.1468-2427.1988.tb00448.x

Shaughnessy, A. (2012). Jak zostać dizajnerem i nie stracić duszy. Karakter.

Simmel, G. (1997). Filozofia pieniqdza. Wydawnictwo Fundacji Humaniora.

Simon, H. A. (1996). The sciences of the artificial. The MIT Press.

Takeuchi, H., \& Nonaka, I. (1986). The new new product development game. Harvard Business Review. https://hbr.org/1986/01/the-new-new-product-development-game

World Design Organization. (2021). Definition of industrial design. https://wdo.org/about/definition/

Wzornictwo Biznes Zysk. (2021). Projektanci. https://projekt-wbz.com.pl/wizytownik/projektanci 